Note

\title{
ECONOMIC ANALYSIS OF ORGANIC GREENHOUSE LETTUCE PRODUCTION IN TURKEY
}

\author{
Sait Engindeniz ${ }^{1 *}$; Yuksel Tuzel ${ }^{2}$ \\ ${ }^{1}$ Ege University/Faculty of Agriculture - Dept. of Agricultural Economics, 35100 Bornova-Izmir - Turkey. \\ ${ }^{2}$ Ege University/Faculty of Agriculture - Dept. of Horticulture. \\ *Corresponding author <sait.engindeniz@ege.edu.tr>
}

\begin{abstract}
Health issues and environmental concerns have drawn the attention to organic agriculture aiming to protect the natural balance and to produce without damaging the environment. This study aims determining economic feasibility of organic greenhouse lettuce (Lactuca sativa L.) in an on farm trial, to foster organic greenhouse vegetable production in the preservation area of Tahtali Dam, projected as the sole water resource of Izmir, Turkey's third largest. A $384 \mathrm{~m}^{2}$ greenhouse, constructed of galvanized metal tubing anchored and covered with a polyethylene was analyzed to identify typical operation procedures, and to determine unitary construction and operation cost. Organic lettuces were produced during autumn season of 2001-2002, testing different organic fertilizer applications, including two rates of farmyard and poultry manure $\left(30\right.$ and $\left.50 \mathrm{t} \mathrm{ha}^{-1}\right)$ with and without two organic fertilizers based on either bacteria or algae. Economical analysis was performed according to different organic fertilizer applications. Cost, yield, and price data were analyzed to determine the profitability of a typical operation. Net return obtained from organic lettuce growing ranged between us $\$ 0.376$ and us $\$ 0.901 \mathrm{~m}^{-2}$, as a result of different fertilizer applications.
\end{abstract}

Key words: vegetable, organic farming, organic fertilizer, cost analysis

\section{ANÁLISE ECONÔMICA DA PRODUÇÃO ORGÂNICA DE ALFACE EM ESTUFAS NA TURQUIA}

\begin{abstract}
RESUMO: Preocupações sanitárias e ambientais têm atraído a atenção para a prática da agricultura orgânica como meio de proteger o balanço ambiental e produzir sem danificar o ambiente. Este estudo objetiva determinar a viabilidade econômica da produção em estufa da alface (Latuca sativa L.) em um ensaio de campo, a fimm de incentivar a produção orgânica de vegetais na área de preservação do Reservatório Tahtali, projetado como o único recurso hídrico de Izmir, a terceira maior cidade da Turquia. Uma estufa de tubos galvanizados $\left(384 \mathrm{~m}^{2}\right)$, ancorados e cobertos com polietileno, foi analisada para identificar procedimentos operacionais padronizados e determinar custos unitários de construção e operação. Alfaces orgânicas foram produzidas no outono de 2001-2002, testando diferentes aplicações de sobras compostadas e esterco de granja avícola como fertilizantes orgânicos $\left(30\right.$ e $\left.50 \mathrm{t} \mathrm{ha}^{-1}\right)$, com ou sem a adição de fertilizantes comerciais bacterianos ou algais. A análise econômica foi feita de acordo com as quantidades de fertilizantes utilizadas. A determinação da lucratividade foi feita com base na análise de dados de custos, produtividade e preço. O lucro líquido obtido da produção orgânica de alface em estufa variou entre US\$ 0.376 e US\$ $0.901 \mathrm{~m}^{-2}$. Palavras-chave: vegetais, agricultura orgânica, fertilizante orgânico, análise de custo
\end{abstract}

\section{INTRODUCTION}

Protected cultivation is considered to be an intensive production system requiring relatively high investment in several aspects of the production and marketing. However, greenhouses are cropped on an essentially continuous basis, with no possibility for suitable rotations, once the limited crop range results in reduction of soil fertility and rapid build up of soil pests, which hampers production and requires intensive use of chemicals (Hanafi \& Papasolomontos, 1999).
Organic greenhouse vegetable production has high potential for the out-of-season produce market niche, and is a sustainable method of production (Tuzel, 2001). Therefore, there is need for studying production strategies, especially at local level and under grower conditions, allied to economics and cost and return analysis studies. Farmers have discovered that organic farming methods are viable alternatives to conventional farming, but also can be quite costly. A common misconception farmers have about organic farming is the idea that it is low-cost and low-input. It 
is difficult to reach conclusions on comparative profitability of conventional versus organic agricultural production practices, because of the wide range of production methods used in different regions and with different crops, and because of the variable organic price premiums.

Purposes of this study were thus performing an economic analysis of organic lettuce (Lactuca sativa L.) production under greenhouse conditions, and to provide a guide for organic greenhouse lettuce growers budgeting specific cost categories and estimating a net return for the production and sale of organic, greenhouse grown lettuce in Turkey.

\section{MATERIAL AND METHODS}

The experiment was conducted in Menderes, Turkey $\left(38^{\circ} 15^{\prime} \mathrm{N}, 27^{\circ} 28^{\prime} \mathrm{E}\right)$ within the long range protection zone of Tahtalý Dam, as an on-farm trial in a polyethylene (PE) - covered greenhouse $(12 \times 32 \mathrm{~m})$, biult erected with galvanized construction bars, with side and roof ventilations and covered with insect net. The local has a Mediterranean climate, with average annual temperatures for the warmest month (July) and for the coldest month (January) rather similar for the entire river basin. Annual precipitation is circa 700 $\mathrm{mm}$, and average relative humidity is $60 \%$. Seedlings of L. Sativa cv. Lithal, which is resistant to mildew 14, were planted on November 28, 2001 at a density of 11.1 plant $\mathrm{m}^{-2}(0.3 \times 0.3 \mathrm{~m})$.

Four organic fertilizers: (1) poultry manure 30 $\mathrm{t} \mathrm{ha}^{-1}+$ E $2001+$ Allgrow Bioplasma; (2) farmyard manure $50 \mathrm{t} \mathrm{ha}^{-1}$; (3) farmyard manure $30 \mathrm{t} \mathrm{ha}^{-1}+\mathrm{E}$ $2001+$ Allgrow Bioplasma; and (4) poultry manure 50 $\mathrm{t} \mathrm{ha} \mathrm{a}^{-1}$, were tested. Since organic tomato and cucumber were croped during previous growing seasons, one plot was not fertilized.

E 2001 (Agricultural Research Technologies Ltd., Bonham, USA) and Allgrow Bioplasma (Biotech Industry AB, Stockholm, Sweden), commercial organic fertilizers containing bacteria and algea, respectively, were used to increment microorganism activity in the soil. Some physical properties of soil and physical and chemical properties of the tested manures are given in Tables 1 and 2 respectively. E 2001 was applied on December $1^{\text {st }}, 2001$, a rate of $300 \mathrm{~mL}$ per parcel $(25$ $\mathrm{m}^{2}$ ), while Allgrow Bioplasma was applied twice, on December $10^{\text {th }}$ and $24^{\text {th }}, 2001$, at $60 \mathrm{~L} \mathrm{ha}^{-1}$ and $200 \mathrm{~mL}$ per parcel. Plants were grown in accordance with organic standards throughout production. Sticky yellow traps (one per $15 \mathrm{~m}^{2}$ ) were placed above the plant level and moved up as plant grew. Pests and diseases were controlled weekly. Trials were set on a completely randomized design $(n=3), 48$ plants per replicate.
Table 1 - Physical properties of soil.

\begin{tabular}{lc}
\hline $\mathrm{pH}$ & 6.55 \\
\hline Soluble total salts \% & 0.05 \\
$\mathrm{CaCO}_{3} \%$ & 0.67 \\
\hline Sand \% & 63.44 \\
\hline Loam \% & 19.68 \\
\hline Clay \% & 16.88 \\
\hline Structure & Sandy loam \\
\hline Organic matter \% & 2.15 \\
\hline
\end{tabular}

Table 2 - Physical and chemical properties of tested organic manures.

\begin{tabular}{lcc}
\hline Items & Poultry manure & Farmyard manure \\
\hline $\mathrm{pH}$ & 9.00 & 9.10 \\
\hline Soluble total salts \% & 2.11 & 1.92 \\
\hline Org. matter \% & 32.16 & 34.13 \\
\hline Total carbon \% & 18.60 & 19.80 \\
\hline Total nitrogen \% & 1.05 & 1.11 \\
\hline C/N & 17.71 & 17.84 \\
Total phosphorus \% & 1.17 & 0.76 \\
Total potassium \% & 1.70 & 1.50 \\
Total calcium \% & 8.00 & 7.47 \\
Total magnesium \% & 0.92 & 0.76 \\
Total sodium \% & 0.40 & 0.18 \\
Total iron \% & 2.14 & 1.62 \\
Total copper ppm & 48.10 & 1.62 \\
Total zinc ppm & 289.50 & 294.00 \\
Total mangan ppm & 467.20 & 93.10 \\
\hline
\end{tabular}

Yield parameters were registered and economic analysis of each treatment was performed. Total production costs of organic lettuce crop include fixed and variable cost. Variable costs include costs for labor, fertilizer, seed, electricity, certification, marketing, and transportation. Variable costs were calculated by using current input prices and labor costs. Fixed costs include interest on total initial investment, annual initial investment costs, interest on total variable costs, and administrative costs. Total costs were subtracted from total gross return to calculate net return.

Interest on total initial investment costs and total variable costs was calculated by charging a simple interest rate of $11 \%$ (saving deposits interest rates, monetary values on US \$) on one-half of total initial investment costs and total variable costs, once it is possible to grow two crops per year in greenhouses (Hickman \& Klonsky, 1993; Estes \& Peet, 1999; Hood 
\& Snyder, 1999). Administrative costs were estimated to be $2-7 \%$ of total gross production value, or $3-7 \%$ of total costs (Mulayim, 2001; Kiral et al., 1999). Administrative costs were estimated to be $3 \%$ of total variable costs. This method was applied in most previous studies (Engindeniz \& Tuzel, 2002; Engindeniz, 2003; 2004a; 2004b). Depreciation was estimated using the straight-line method. Assets were divided by their useful life expectancies to determine annual costs for depreciation. The greenhouse was exempted from property tax and was not insured.

It was assumed that land was rented at $\$ 58$ (\$ 29 for each of two crops) per year. This figure can be highly variable and depends on location, since factors such as soil type and water availability affect land rental prices.

\section{RESULTS AND DISCUSSION}

\section{Yield}

Lettuces were harvested on March 12, 2002 and March 15, 2002. The effect of organic fertilizers on yield was not significantly different (Table 3 ). Also organic fertilizers did not affect average head weight, number of waste leaves, and net plant weight. Total yield, average head weight, number of waste leaves and net plant weight varied between $11.56-13.20 \mathrm{~kg}$ $\mathrm{m}^{-2}, 1040.3-1188.4 \mathrm{~g}, 2.38-3.27$, and $1025.86-$ $1177.81 \mathrm{~g}$, respectively.

In general lettuce yields range on 20 and $60 \mathrm{t}$ $\mathrm{ha}^{-1}$ in open field, and 40 and $120 \mathrm{tha}^{-1}$ in greenhouse conditions, depending on variety, plant density, climatic conditions, growing season, and related agricultural practices (Aybak, 2002). Although an average crop yield reduction of $20 \%$ is accepted as normal (FIBL, 2004), no yield loss was registered in the experiment. Also, the average head weight, which is circa $1 \mathrm{~kg}$ in conventional lettuce production in the same region (N. Aykut, personal communication), showed similar performance in the organic production. Among the fertilizer treatments, the plot which was not ma- nured recorded higher yields as a result of previous fertilizations for organic tomato and cucumber crops.

\section{Costs}

Costs associated with the production of organic greenhouse lettuce are classified as initial investment costs, variable costs, fixed costs, and total production costs (Tables 4, 5, and 6). The initial investment costs of the organic lettuce greenhouse were $\$ 6,814$. Therefore, initial investment costs were $\$ 17.744 \mathrm{~m}^{-2}$ (Table 4). Galvanized frame and kit, base locking rail and assembly and installation costs comprised $76.6 \%$ of the total initial investment. Annual initial investment costs were $\$ 1.599 \mathrm{~m}^{-2}$. Since farmers can grow two crops per year in the region, semi-annual, initial investment cost was $\$ 0.799 \mathrm{~m}^{-2}$ for organic lettuce production in autumn season. Total and annual investment costs may increase if a more elaborate environmental control system, specific substrate materials, or multiple gutterconnected houses are used or built.

In a previous study in the same area, initial investment cost of a $1,344 \mathrm{~m}^{2}$ greenhouse was estimated to be $\$ 8.66 \mathrm{~m}^{-2}$ (Engindeniz, 2003), whereas the capital requirement of a $1,035 \mathrm{~m}^{2}$ greenhouse in which soilless culture system is used, was estimated on $\$ 14.50 \mathrm{~m}^{-2}$ (Engindeniz, 2004a). The simple and cheap greenhouse structure (iron construsction, no roof ventilation, etc.) in the region caused such a difference in the initial cost.

Total variable costs varied between $\$ 0.366$ and $\$ 0.398 \mathrm{~m}^{-2}$ depending on the quantities of organic fertilizer utilized (Table 5). Inspection and certification, and labor costs were between 40.8 and $41.6 \%$, and 28.7 and $29.1 \%$ of total variable cost, respectively.

Total cost of organic greenhouse lettuce production varied between $\$ 2.247$ and $\$ 2.282 \mathrm{~m}^{-2}$, depending on the organic fertilizer applicated (Table 6). On the other hand, total cost of soilless lettuce production was calculated to be $\$ 0.694 \mathrm{~m}^{-2}$ (Engindeniz, 2004b). The difference could be mainly due to the higher initial cost and inspection and certification of organic lettuce production costs.

Table 3 - Changes in yield and yield related parameters.

\begin{tabular}{lcccc}
\hline Organic fertilizer applications & Yield & $\begin{array}{c}\text { Average head } \\
\text { weight }\end{array}$ & $\begin{array}{c}\text { Number of } \\
\text { waste leaves }\end{array}$ & Net weight \\
\hline & $\mathrm{kg} \mathrm{m}^{-2}$ & g per plant & g per plant \\
Farmyard manure $\left(15 \mathrm{t} \mathrm{ha}^{-1}\right)+\mathrm{E} 2001+$ allgrow bioplasma & 13.20 & $1,188.38$ & 2.72 & $1,177.81$ \\
Farmyard manure $\left(30 \mathrm{t} \mathrm{ha}^{-1}\right)$ & 11.85 & $1,066.24$ & 2.53 & $1,050.33$ \\
Poultry manure $\left(15 \mathrm{t} \mathrm{ha}^{-1}\right)+\mathrm{E} 2001+$ allgrow bioplasma & 12.37 & $1,113.24$ & 2.38 & $1,097.29$ \\
Poultry manure $\left(30 \mathrm{t} \mathrm{ha}^{-1}\right)$ & 11.56 & $1,040.28$ & 2.81 & $1,025.86$ \\
Control (no fertilizer) & 12.61 & $1,134.72$ & 3.27 & $1,118.26$ \\
\hline
\end{tabular}

*Means are not significantly different at the 0.05 level of probability according to Least Means Square test. 
Table 4 - Initial Investment costs for greenhouse construction.

\begin{tabular}{|c|c|c|c|c|c|}
\hline Item & Initial Cost & & Useful Life & Annual Cost & \\
\hline & $\$ \mathrm{~m}^{-2}$ & $\%$ & Years & $\$ \mathrm{~m}^{-2}$ & $\%$ \\
\hline Galvanized frame and kit & 4.742 & 26.7 & 20 & 0.237 & 14.8 \\
\hline Base locking rail & 4.076 & 23.0 & 20 & 0.204 & 12.7 \\
\hline PE (covering material) & 0.687 & 3.9 & 2 & 0.343 & 21.5 \\
\hline Ground cover (for solarization) & 0.141 & 0.8 & 2 & 0.070 & 4.4 \\
\hline Roof sprinkler (for frost protection) & 0.516 & 2.9 & 20 & 0.026 & 1.6 \\
\hline Water pipe (PVC) & 0.078 & 0.4 & 15 & 0.005 & 0.3 \\
\hline Water pipe (dropping) & 0.268 & 1.5 & 10 & 0.027 & 1.6 \\
\hline Plastic filter & 0.044 & 0.3 & 10 & 0.004 & 0.3 \\
\hline Metal filter & 0.088 & 0.5 & 10 & 0.009 & 0.5 \\
\hline Nipple & 0.026 & 0.2 & 10 & 0.003 & 0.2 \\
\hline Elbow (PVC) & 0.039 & 0.2 & 15 & 0.003 & 0.2 \\
\hline Valve & 0.104 & 0.6 & 15 & 0.007 & 0.5 \\
\hline Pressure regulation tank & 0.161 & 0.9 & 15 & 0.011 & 0.7 \\
\hline Water pump & 0.849 & 4.8 & 15 & 0.057 & 3.6 \\
\hline Site preparation and gravel base & 1.146 & 6.4 & - & $0.115^{*}$ & 7.2 \\
\hline Assembly and installation & 4.779 & 26.9 & - & $0.478 *$ & 29.9 \\
\hline Total $\left(\$ \mathrm{~m}^{-2}\right)$ & 17.744 & 100.0 & - & 1.599 & 100.0 \\
\hline
\end{tabular}

*It was calculated over 10 years (Hickman \& Klonsky, 1993; Estes \& Peet, 1999; Hood\&Snyder, 1999).

Table 5 - Variable costs for organic greenhouse lettuce production depending on the different organic fertilizer applications.

\begin{tabular}{|c|c|c|c|c|c|}
\hline \multirow{3}{*}{ Operation } & \multicolumn{5}{|c|}{ Organic fertilizer applications } \\
\hline & Farmyard manure & Farmyard manure & Poultry manure & Poultry manure & Control \\
\hline & $\begin{array}{c}\left(15 \mathrm{t} \mathrm{ha}^{-1}\right)+\text { E } 2001+ \\
\text { allgrow bioplasma }\end{array}$ & $\left(30 \mathrm{tha}^{-1}\right)$ & $\begin{array}{c}\left(15 \mathrm{t} \mathrm{ha}^{-1}\right)+\mathrm{E} 2001+ \\
\text { allgrow bioplasma }\end{array}$ & $\left(30 \mathrm{t} \mathrm{ha}^{-1}\right)$ & (no fertilizer) \\
\hline $\begin{array}{l}\text { Plowing } \\
\text { (machine labor) }\end{array}$ & 0.016 & 0.016 & 0.016 & 0.016 & 0.016 \\
\hline Hoeing (labor) & 0.029 & 0.029 & 0.029 & 0.029 & 0.029 \\
\hline Fertilization (labor) & 0.016 & 0.013 & 0.016 & 0.013 & - \\
\hline Poultry manure & - & - & 0.005 & 0.010 & - \\
\hline Farmyard manure & 0.008 & 0.013 & - & - & - \\
\hline Bioplasm & 0.005 & - & 0.005 & - & - \\
\hline E-2001 & 0.003 & - & 0.003 & - & - \\
\hline Peat & 0.016 & 0.016 & 0.016 & 0.016 & 0.016 \\
\hline Seed & 0.005 & 0.005 & 0.005 & 0.005 & 0.005 \\
\hline Planting (labor) & 0.013 & 0.013 & 0.013 & 0.013 & 0.013 \\
\hline Irrigation (labor) & 0.018 & 0.018 & 0.018 & 0.018 & 0.018 \\
\hline Electricity & 0.008 & 0.008 & 0.008 & 0.008 & 0.008 \\
\hline $\begin{array}{l}\text { Plant protective } \\
\text { applications (labor) }\end{array}$ & 0.003 & 0.003 & 0.003 & 0.003 & 0.003 \\
\hline Copper & 0.003 & 0.003 & 0.003 & 0.003 & 0.003 \\
\hline Yellow traps & 0.003 & 0.003 & 0.003 & 0.003 & 0.003 \\
\hline Glue (for traps) & 0.003 & 0.003 & 0.003 & 0.003 & 0.003 \\
\hline $\begin{array}{l}\text { Inspection and } \\
\text { certification }\end{array}$ & 0.161 & 0.161 & 0.161 & 0.161 & 0.161 \\
\hline Harvest (labor) & 0.023 & 0.023 & 0.023 & 0.023 & 0.023 \\
\hline Wrapping (labor) & 0.013 & 0.013 & 0.013 & 0.013 & 0.013 \\
\hline Plastic bag & 0.005 & 0.005 & 0.005 & 0.005 & 0.005 \\
\hline Transport & 0.047 & 0.047 & 0.047 & 0.047 & 0.047 \\
\hline Total $\left(\$ \mathrm{~m}^{-2}\right)$ & 0.398 & 0.392 & 0.395 & 0.389 & 0.366 \\
\hline
\end{tabular}




\section{Marketing and Pricing}

The harvested organic greenhouse lettuces were marketed at specific organic shops and supermarkets after packing in plastic bags, and sold for an average $\$ 0.90$ per head. Results of a survey conducted with lettuce producers showed that the price of conventional lettuces varies between $\$ 0.18$ and $\$ 0.28$ per head. Also, average price of soilless lettuces was calculated to be $\$ 0.26$ per head (Engindeniz, 2004b). Although the initial and total costs of organic lettuce production was higher in the present study, the price of organic lettuce was 3.5 fold higher due to the premium in organic production. Organic products can be sold at a higher price than the conventional ones. The consumers usually agree to to pay $20-25 \%$ premium for organic food (Engindeniz \& Tuzel, 2002).

\section{Gross Return and Net Return}

Total gross return obtained from organic greenhouse lettuces varied between $\$ 2.648$ and $\$ 3.177 \mathrm{~m}^{-2}$, depending on the organic fertilizer applicated. However, it was determined that the total net return varied between $\$ 0.376$ and $\$ 0.901 \mathrm{~m}^{-2}$ depending on the organic fertilizer applicated (Table 7). Net return obtained from conventional lettuce production vary between $\$ 0.155$ and $\$ 0.650 \mathrm{~m}^{-2}$ in the same region. Also, net return obtained from soilless lettuces was calculated to be $\$ 0.188 \mathrm{~m}^{-2}$ (Engindeniz, 2004b).

\section{CONCLUDING REMARKS}

The organic greenhouse lettuce project was successful in developing and demonstrating different organic fertilizer applications for growers to produce high quality lettuces. Utilization of organic fertilizers could turn popular for small growers of the region, especially where production space or farm equipment is limited. Using organic fertilizer appears to be quite successful for small growers who want to intensively produce lettuces for their own use or for sale.

Organic lettuce production is an economically viable alternative for growers, although materials and total costs are higher for organic farming system compared to conventional farming. Especially, organic let-

Table 6 - Total costs of organic greenhouse lettuce production depending on the different organic fertilizer applications.

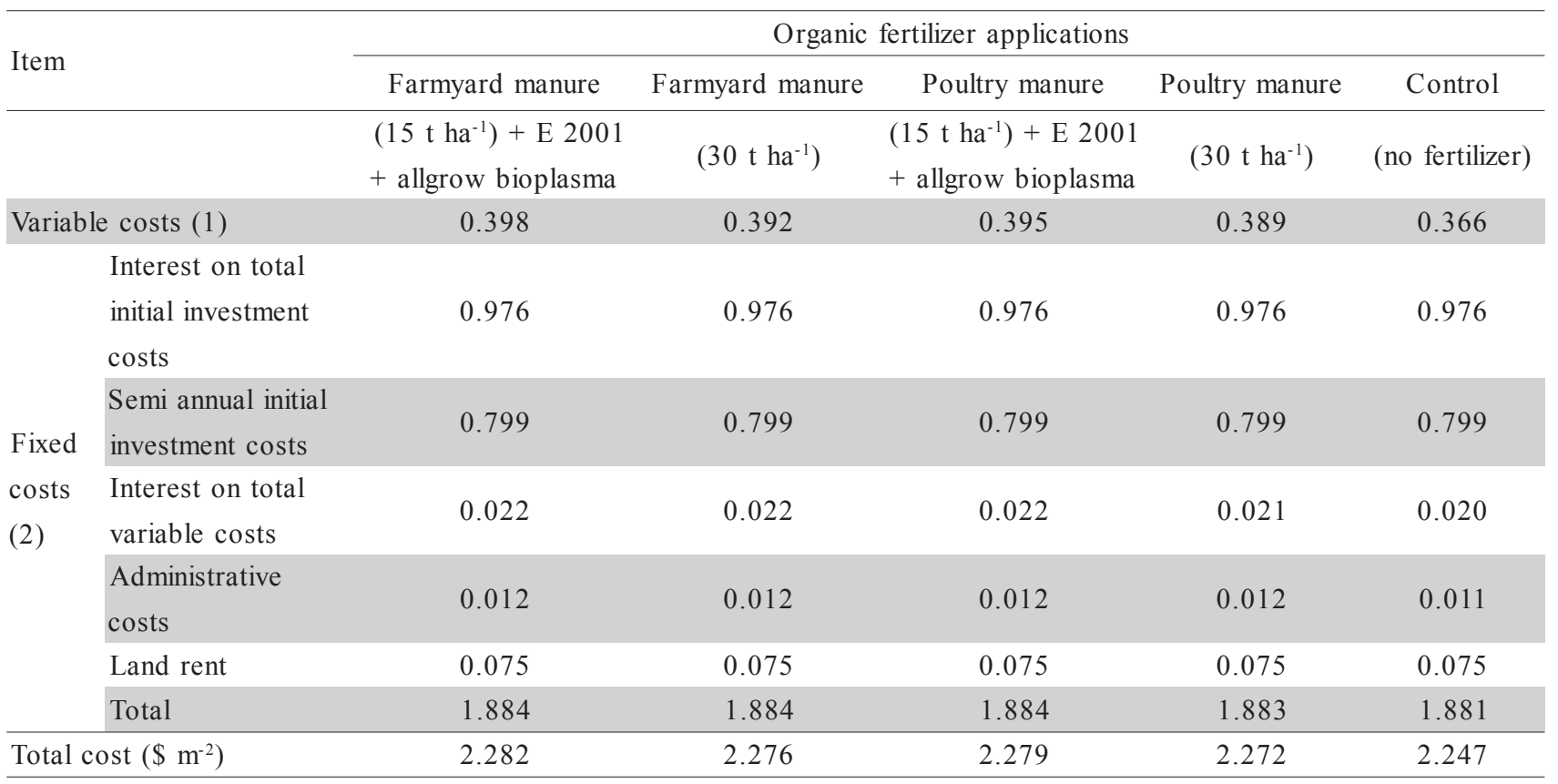

Table 7 - Total net return and gross return obtained from organic greenhouse lettuces.

\begin{tabular}{lccccc}
\hline \multirow{2}{*}{ Item } & \multicolumn{5}{c}{ Organic fertilizer applications } \\
\cline { 2 - 6 } & Farmyard manure & Farmyard manure & Poultry manure & Poultry manure & Control \\
\hline & $\begin{array}{l}\left(15 \mathrm{t} \mathrm{ha}^{-1}\right)+\mathrm{E} 2001 \\
+ \text { allgrow bioplasma }\end{array}$ & $\left(30 \mathrm{tha}^{-1}\right)$ & $\begin{array}{l}\left(15 \mathrm{t} \mathrm{ha}^{-1}\right)+\mathrm{E} 2001 \\
+ \text { allgrow bioplasma }\end{array}$ & $\left(30 \mathrm{t} \mathrm{ha}^{-1}\right)$ & $($ no fertilizer $)$ \\
Total gross return $(\$)(1)$ & 2.966 & 3.177 & 2.883 & 2.648 & 2.943 \\
Total costs $(\$)(2)$ & 2.282 & 2.276 & 2.279 & 2.272 & 2.247 \\
Net return $\left(\$ \mathrm{~m}^{-2}\right)(1-2)$ & 0.684 & 0.901 & 0.604 & 0.376 & 0.696 \\
\hline
\end{tabular}


tuce production with farmyard manure $\left(30 \mathrm{t} \mathrm{ha}^{-1}\right)$ is more profitable than others. Organic farming costs are expected to decrease as sales continue to increase and these systems become more profissionalized.

Many organic agricultural producers are producing on a small scale, and have not yet established a sales network because of the high operation costs and, therefore, have difficulties reaching the consumers. With the establishment of various producer organizations and increase in the production scale, it is believed that this problem will be solved over the following years.

\section{ACKNOWLEDGEMENT}

This research has been supported by TUBITAK (Scientific and Technical Research Council of Turkey), IZSU (Municipality of the city of Izmir) and EBILTEM (Ege University Science and Technology Application and Research Center).

\section{REFERENCES}

AYBAK, H.C. Lettuce growing (Turkish). Istanbul: Hasad, 2002. 96p. ENGINDENIZ, S. An economic analysis of growing conventional greenhouse tomatoes in Turkey. Practical Hydroponics and Greenhouses, v.69, p.63-66, 2003.

ENGINDENIZ, S. The economic analysis of growing greenhouse cucumber with soilless culture system: the case of Turkey. Journal of Sustainable Agriculture, v.23, p.5-19, 2004a.

ENGINDENIZ, S. An economic analysis of a greenhouse lettuce production model (soilless culture) in Turkey. Practical Hydroponics and Greenhouses, v.78, p.56-59, 2004b.
ENGINDENIZ, S.; TUZEL, Y. The economic analysis of organic greenhouse tomato production: a case study for Turkey. Agro Food Industry Hi-Tech, v.13, p.26-30, 2002.

ESTES, E.A.; PEET, M. The bottom line in greenhouse tomato production. Raleigh: North Carolina State University, Department of Agricultural and Research Economics, 1999. 20p. (Report, 18).

FORSCHUNGSINSTITUT FÜR BIOLOGISCHEN LANDBAU / RESEARCH INSTITUTE OF ORGANIC AGRICULTURE - FiBL. Do organic systems produce sufficient yield? Frick, Switzerland, 2004. Available in: http://www.fibl.org/english/research/annualcrops/dok/yields.php. Accessed at: May 30, 2005.

HANAFI, A.; PAPASOLOMONTOS, A., Integrated production and protection under protected cultivation in the Mediterranean Region. Biotechnology Advances, v.17, p.183-203, 1999.

HICKMAN, G.W.; KLONSKY, K. Greenhouse cucumbers-bag culture. cost of production and equipment in San Joaquin Valley. Stocton: University of California, Vegetable Research and Information Center, 1993. 3p.

HOOD, K.; SNYDER, R. Budget for greenhouse tomatoes. Raymond: Mississippi Extension Service of Mississippi State University, 1999. $6 \mathrm{p}$.

KIRAL, T.; KASNAKOGLU, H.; TATLIDIL, F.; FIDAN, H., GUNDOGMUS, E. Database guide and income and cost calculation methodologie for agricultural products (Turkish). Ankara: Agricultural Economics Research Institute, 1999. 133p. (Publication, 37).

MULAYIM, Z.G. Agricultural valuation and expertise (Turkish). 2.ed. Ankara: Yetkin, 2001. 367p.

TUZEL, Y. Organic vegetable growing in the greenhouses. Regional WG Greenhouse Crop Production in the Mediterranean Region. Newsletter, n.8, p.7-17, 2001.

Received November 19, 2004

Accepted March 13, 2006 